Comparative Philosophy Volume 12, No. 2 (2021): 32-57

Open Access / ISSN 2151-6014 / www.comparativephilosophy.org

https://doi.org/10.31979/2151-6014(2021).120205

\title{
BETWEEN MYSITICISM AND PHILOSOPHICAL RATIONALITY: AL-GHAZĀLĪ ON THE REASONS OF THE HEART
}

\author{
MARILIE COETSEE
}

\begin{abstract}
In his seminal Orientalism and Religion (1999), Richard King argues that Western scholars of religion have constructed a conceptual dichotomy between "mysticism" and "rationality" that has caused them to systematically distort the claims and arguments of Eastern thinkers. While King focuses primarily on Western scholarship on the Buddhist and Hindu traditions, this essay shows that his argument can also be extended to apply to Western scholarship on al-Ghazäli, whose sympathy for Sufism and apparent rejection of Greek philosophy has often earned him the reputation of being a champion of Islamic mysticism. I argue that al-Ghazāli transcends the dueling categories of 'rationality' and 'mysticism' that have been imposed on him by offering a conception of experiential knowledge that retains its roots in the 'mystical' Sufi tradition, even while also highlighting the rational merits of experientially-grounded modes of knowing. In particular, I argue that al-Ghazāli shows us how experiential knowledge is both important to providing motivation for rational action and also critical to underwriting persons' genuine understanding of the evaluative properties of that which is known.
\end{abstract}

Keywords: Al-Ghazālī, cognitive emotions, experiential knowledge, Ibn Sinna, mysticism, Sufism

In his seminal Orientalism and Religion (1999), Richard King argues that Western scholars of religion have constructed a conceptual dichotomy between "mysticism" and "rationality" that has been used, both within and without the academy, as a tool to manage and marginalize the Orient. According to King, nineteenth and twentieth century academics' use of the category of the "Mystic East" not only served to homogenize diverse patterns of life and thought in the Orient $(79,98-101)$, but alsoindirectly - to help justify various forms of their subordination to the 'rational' West. In portraying Eastern traditions of thought as "mystical", King argues, Western academics have created grounds for dismissing the insights of these traditions as

COETSEE, MARILIE: Assistant Professor of Leadership Studies, University of Richmond, USA. Email: mcoetsee@richmond.edu 
"inscrutable" and "private" (2-3, 7ff). By contrast, by characterizing Western thought as "rational", he claims, Western scholars bestowed on their own work a kind of "public" scholarly authority denied to the East (8-14, 28-34, 82ff). Besides helping to prop up pernicious exercises of Western colonial power over Eastern societies (192-193), ${ }^{1} \mathrm{King}$ argues, Western scholars' use of these categories of "rationality" and "mysticism" has also served to undermine the reliability of their (supposedly) "authoritative" scholarship on Eastern traditions. Since, according to King, the dichotomy between "rationality" and 'mysticism' is alien to the Eastern texts on which Western academics impose it, Western interpretations of those texts often distort their intended meanings (161ff).

King is most concerned to highlight how the assumed dichotomy between "rationality" and "mysticism" has distorted Western scholarship on Buddhism and Hinduism, ${ }^{2}$ but in this paper I show how a version of his argument can also be extended to apply to Western scholarship on al-Ghazālī, whose sympathy for the Sufi tradition and apparent rejection of Greek philosophy has often earned him the reputation of being a champion of Islamic mysticism. ${ }^{3}$ I will argue that al-Ghazāli transcends the dueling categories of "rationality" and "mysticism" that have been imposed on him by offering a conception of the experiential knowledge of the "heart" that retains roots in the "mystical" Sufi tradition, even while also highlighting the rational merits of experientially-grounded modes of cognition.

The essay will proceed as follows. In the first section, I briefly review how nineteenth and early twentieth century scholars like Ernest Renan and William James portrayed al-Ghazālī as a mystical anti-rationalist, and argue that-even though alGhazāli does emphasize the kind of experiential knowledge that they associate with mysticism - he does not fit the anti-rationalistic stereotypes that they impose on him. In the second section, I then go on to explore a more recent trend in al-Ghazâli scholarship, which reinterprets him as a closet philosophical rationalist. In particular, I look at the work of Alexander Treiger (2012), who argues that al-Ghazālī's discussions about the ("mystical') religious experiences of the "heart" largely serve as strategic covers to disguise his acceptance of Ibn Sīnā's philosophical conception of

\footnotetext{
${ }^{1}$ King argues that since persons' patterns of life and thought in the East are judged not only to be "mystical", but also - in virtue of that - as "inscrutable" and "private", those persons are also easily characterized as requiring the political oversight of "public", "rationally" justified Western forms of power. Although elements of this argument are found throughout the book, see especially chapter 4 , "Orientalism and Indian Religions" and chapter 8, "The Politics of Privatization: Indian Religion and the Study of Mysticism".

${ }^{2}$ King provides several case studies to support his argument; see chapters five and six for his discussion of Western constructions of (what he calls) the "myth" of Hinduism, and see chapter seven for his discussion of Western scholarship on Buddhism. See also Jantzen 1989 for similar discussion of scholarship on Christian mystic traditions.

${ }^{3}$ See below discussion on Renan and James, as well as Footnote 4 for more references. While King's original argument is intended to show that the dichotomy between rationality and mysticism distorts both Western scholarship on Buddhism and Hinduism and the relationships of power between the West and those who partake in these traditions, I will focus on the distorting effects of that dichotomy primarily on Western scholarship on al-Ghazālī.
} 
the "rational soul" - a conception of the soul that draws on the Aristotelian tradition and emphasizes the value of conceptual knowledge and syllogistic deduction. I argue that this rationalist interpretation of al-Ghazāli fails to take adequately seriously the central role that experiential knowledge plays for him. Finally, in the third section I show that al-Ghazāli offers a novel way of understanding the (so called) 'mystical' experiences of the heart that brings to light the rational merits of such experiences. I argue that al-Ghazāli points us to two important insights about the rational merits of experiential cognition that Western analytic philosophers have just recently begun to appreciate: that is, first, that experiential cognition is important to underwriting motivation for rational action and, second, that affective experience in particular is critical to supporting persons' genuine understanding of the evaluative properties of the objects of their knowledge.

\section{AL-GHAZĀLĪ AS ANTI-RATIONALIST MYSTIC}

In his 1852 Averroès et l'Averroïsme, Ernest Renan helped inaugurate a long-standing trend in Western scholarship on al-Ghazālī in which scholars consistently portrayed him, not only as a champion of Sufi mysticism, but also as someone who was hostile to philosophy - and, indeed, to 'rational' avenues to attaining knowledge, more broadly. ${ }^{4}$ Focusing on al-Ghazālī's The Incoherence of Philosophers, Renan treats alGhazālī's arguments against Ibn Sīnā's Aristotelian-inspired metaphysics as grounds to regard him as an "enemy of philosophy" (Griffel 2011, 37, 40). Then, conflating philosophy with the larger category of 'reason,' he goes on to characterize al-Ghazāli as mounting an "attack against rationalism" (97), more generally.

Although Renan is in some respects right to identify al-Ghazālī as a champion of (so called) 'mystical' experiential knowledge,${ }^{5}$ Renan makes a mistake in also claiming that al-Ghazāli is an opponent of philosophy or of "rationality" more generally. His mistake is rooted in a double conflation-first, between Ibn Sīnā's Aristotelian metaphysics and philosophy, ${ }^{6}$ and second, between philosophy and rationality more generally. The first conflation is perhaps more excusable than the second, since alGhazālī himself sometimes treats Ibn Sīnā's Aristotelian metaphysics as interchangeable with "philosophy" in his Incoherence of the Philosophers. ${ }^{7}$ That said, al-Ghazālī's criticism of Avicennan-Aristotelian metaphysics in the Incoherence need not be understood as a rejection of philosophy as a whole. For one thing, as Peter Adamson (2006) suggests, the word often translated as "incoherence" in the title of the

\footnotetext{
${ }^{4}$ See discussion on William James later in this section. See also: DeBoer 1903, 154-168; Arberry 1957/2008, 61, Oliver Leaman 1985/2002, Part 1. (The references to Arberry and Leaman are from Ahmad 2007, 62.)

${ }^{5}$ I briefly discuss this issue in this section but make a more detailed argument for this idea in Sections 2 and 3.

${ }^{6}$ For more on the influence of the Aristotelian tradition on Ibn Sīnā's philosophy, see Gutas 2014.

${ }^{7}$ It is not surprising that al-Ghazāli would have done this, since the relevant term of falasifa that is now translated as "philosophy" was in al-Ghazālī's time already specifically associated with those who identified themselves with the Aristotelian tradition.
} 
book - tahäfut - is plausibly better translated in context as something like "a reckless stumble into error", and the content of the argument contained in the book is arguably better understood as a criticism of the ways in which Avicennan-Aristotelian metaphysicians have overreached-claiming to have proved more than they have actually proved - rather than an wholesale rejection of the value of philosophy (147). Additionally, once we look past the Incoherence to al-Ghazālī's Revival of Religious Science, we see that although al-Ghazâli may think that some philosophers have wrongly strayed into "unbelief" and "innovation", he still also recognizes that philosophy as whole offers valuable intellectual training on "the science of the being and attributes of God", as well as the topics of logic and physics $(1962,46-47) .^{8}$

In addition to there being good evidence that al-Ghazālì was not, as Renan suggests, an "enemy" of philosophy, there are also strong prima facie reasons to think that alGhazālī was not antagonistic to 'rationality' in any more general sense. For instance, al-Ghazālī argues that our powers of intelligence have a "noble nature" that constitute our "glory" before Allah, make us superior to other animals, and serve as our "means of happiness in this world and the next" $(1962,213)$. Further, whenever al-Ghazâli describes the structure of the soul, he always places our powers of intellect in the top position, as the proper and authoritative governor of the soul. ${ }^{9}$ Thus, for instance, when he compares the soul to a horseman who has gone hunting with his dog, it is the intellect that serves as the horseman. This horseman (the intellect) is tasked with keeping the "horse" - the soul's "appetence" — and the "dog"- the soul's anger - under proper control, and al-Ghazāli notes that if the metaphorical "hunt" succeeds, it is only because of the horseman's skill-i.e., because of the development of a person's intellect (1977, 23-24).

In light of the above, one might wonder why Renan's early portrayal of al-Ghazāli as someone who mounted an "attack against rationalism" would be able to exert the kind of persistent influence on al-Ghazālī scholarship that it did. ${ }^{10}$ One potential explanation for this persistence lies in the strength of the assumed dichotomy between 'mystical' experience and 'rational' cognition. Al-Ghazālī identifies the intellect with the heart, ${ }^{11}$ and - though he grants that the heart's knowledge may in critical ways be supported by (e.g.) powers of syllogistic deduction $(1977,52)^{12}$-he claims that the

\footnotetext{
${ }^{8}$ See also footnote 12 .

${ }^{9}$ Besides the example I provide here, al-Ghazāli also offers several other examples of the same kind: the intelligent power is a "sage" compared with the pig, dog, and demon-like parts of the soul (1977, 20-24), and it is the "king" who rules over the "city" of the body (37-38).

${ }^{10}$ See Footnote 4 for references.

${ }^{11}$ For further discussion of this idea, see Section 2.

${ }^{12}$ I discuss this at length in Section 2. Besides what I discuss there, one might also note that in Book 21 of the Revival, The Marvels of the Heart, al-Ghazāli suggests that the methodology of the syllogistic deduction — the methodology also most distinctively associated with Aristotelian philosophy — is a necessary scaffolding on the pathway to knowledge. Al-Ghazāli argues that, just as someone who wants to see the back of his neck must know how to align and angle two mirrors to get a clear view of his desired object of knowledge, so also someone who seeks knowledge, more generally, must be able to structure and order the premises in a syllogism, in order to get a clear view of that which he wishes to know $(1977,52)$.
} 
real nobility of the heart consists in its capacity to gain "experiential knowledge (ma'rifa) of the real nature of things" (1977, 32; emphasis added). It is thus first and foremost as an experiential "perceptive power" that al-Ghazāli regards the intellecti.e., the heart - as the ruler of the soul (32). If, as King argues, Renan's generation of scholars assumed a strong dichotomy between 'mystical' experiences and 'rational' avenues to knowledge, then al-Ghazâlī's placement of experiential knowledge at the crown of our human powers of intelligence may simply have seemed like a category error them. Rather than considering how al-Ghazālī's claims about the importance of experiential cognition might have challenged their assumptions about the category of the "rational", it seems that Renan and his later followers may have allowed their presuppositions about the nature of that category to serve as grounds for dismissing alGhazālī's many positive general claims about human beings' powers of intelligence, as well as his more specific assertions about the value of philosophy and the method of syllogistic deduction.

A half-century after Renan's Averroès et l'Averrö̈sme, William James depicted alGhazālī as the representative of the mystical tradition in Islam in his Varieties of Religious Experience. Although James was more friendly to the epistemic merits of mystical experience than some of his contemporaries, ${ }^{13}$ he still assumed a strong distinction between the categories of 'mysticism' and 'rationality'. In the remainder of this section, I look more closely at James's argument for making this distinction and show how al-Ghazāli gives us reasons to doubt the cogency of that argument.

After introducing the Sufi "sect" as the "possessors of the mystical tradition" in Islam, James provides an extended excerpt from al-Ghazālī's Deliverance from Error as an illustration of Sufi thinking (1902/2002, 311). A key passage in this translation that encapsulates what James finds remarkable about al-Ghazāli- - and that will also turn out to be important to the argument of this essay-is the following:

[1] How great... is the difference between knowing the definitions of health, of satiety, with their causes and conditions, and being really healthy or filled. How different to know in what drunkenness consists and being drunk effectively... Similarly there is a difference between knowing the nature of abstinence, and being abstinent or having one's soul detached from the world. - Thus I learned what words could teach of Sufism, but what was left could be learned neither by study nor through the ears, but solely by giving up one's self up to ecstasy and leading a pious life. (Quoted in James 1902/2002, 312)

Drawing on this passage and the surrounding text in al-Ghazālī's Deliverance from Error, James goes on to argue that al-Ghazâli displays what he regards as the key distinguishing characteristic of "mystical" thinkers: that is, that he points to an

13 James is more friendly to the epistemic merits of mystical experience than some of his contemporaries - while (for instance) Immanuel Kant had disparaged mysticism as merely "counterfeit philosophy" (1800/1978, 8: 441; see also King's discussion of Bertrand Russell 1999, 32-33), James claims that it must in principle be left open that mystical states could be "superior points of view" that provide "windows" into "a more extensive and inclusive world" (1902/2002, 331). Despite this admission, however, James goes on to distinguish mysticism from philosophy by pointing to the superior rationalistic credentials of the latter. (I discuss this further in the main text.) 
"ineffable", "incommunicable" experience as the basis for knowledge (314). Though James grants that such 'mystical' experiences have merits as sources of psychological delight and motivation, he argues that from the standpoint of reason, the insights of such experiences must be subordinated to the superior, more "rational" conclusions of philosophy. Thus, James writes that while mystical state is "excitements like the emotions" that allow us to establish "new connections" between "facts already objectively before us" and "our active life" (331), philosophy takes the "first hint" supplied by those feelings, and "deal[s] [with them] in a superior way" (334). While states of mystical experience are "private and dumb", he claims, philosophy is able to "redeem [those states] from unwholesome privacy" because it "lives in words" and uses "coercive" arguments to establish truths that are "objectively valid for all thinking men" (334). By thus executing "reason's task", he writes, philosophy helps humanity "escape from obscure and wayward personal persuasion" to find "truth objectively valid for all thinking men" (334). ${ }^{14}$

As suggested by the above quotations, James argues that the distinction between the "rational" nature of philosophy and the "non-rational" nature of mysticism rests on the fact that philosophy uses discursive argumentation to draw its conclusions, while "mystical" avenues to knowledge draw only on ineffable experience. ${ }^{15}$ But al-Ghazālī's work allows us to challenge the merits of these grounds for making that distinction. Why should the ineffability of mystical experience undermine the rational credentials of its deliverances?

James doesn't offer any independent criterion of "rationality" by which we can deduce that the ineffability of mystical experience must make it fail, where discursive

${ }^{14}$ Like Renan, James seems to assume that the distinction between mystical experience and philosophical argumentation can be mapped onto a more general distinction between mystical experience and rationality. Further, and importantly, this distinction in the rational statuses of the two activities - that is, the (alleged) rationality of philosophy and (alleged) non-rationality of mysticismseems to be used to account for the (alleged) result that philosophical claims are "public" and mystical claims "private." The deliverances of mysticism remain in the domain of "personal persuasion", it appears, because mystics "decline to justify [their results] rationally, whereas (it appears) philosophy helps humanity to "escape from obscure and wayward personal persuasion" because it executes "reason's task". Though it appears that what is supposed to provide grounds for the conclusion about the "private" nature of mystical claims and the "public" nature of philosophical claims is that the latter philosophical claims are "rational" while the former mystical claims are not, James does not provide adequate resources to support this argument. To make that argument successful, James would need to offer an independent criterion of rationality that allow us to distinguish between philosophy and mysticism and explain how the presence of that kind of rationality uniquely gives rise to "public" results. But James does not appeal to any such independent criteria for what "rationality" is supposed to consist in. There is a further problem as well. For all we are told, there is little reason to think that it is because mystical experience fails to achieve criteria of rationality that it is "private". For all we are told, it may just as well be the other way round: it may be because mystical experience has already been deemed "private" that it is also pronounced to be non-rational (even withstanding its similarities to more "rational" experiences). Likewise, for all we are told, there is little reason to think that it is because philosophy executes "reason's task" that it gives "public status and universal right of way" to its claims; it may just as well be that it is because it's claims have been given the status of being "public", that they are also pronounced to be "rational".

${ }^{15}$ For more on this, see James 1902/2002, 295, 314. 
argumentation succeeds, at being able to deliver rationally justified beliefs. Indeed, to the contrary, James briefly admits that mystical experience plays a role exactly correlate to the role that our own ordinary experiences play in supporting our (supposedly) more 'rational' beliefs: our own "more 'rational' beliefs", James acknowledges, "are based on evidence exactly similar in nature to that which mystics quote for theirs", since mystical experiences are "as direct perceptions of fact for those who have them as any sensations ever were for us" (328). Despite initially acknowledging this parity in the evidential status of 'mystical' and 'rational' experience, however, James does not go on to discuss the consequences of this parity for his larger argument about the distinction between 'mystical' and 'rational' avenues to knowledge. ${ }^{16}$

Where James fails to follow through on the parity between the rational merits of "mystical" experience and our "ordinary" sensations, al-Ghazālī picks up on and advances the argument. In the extended passage of al-Ghazālì's that James quotes (of which [1] above is a part), al-Ghazālī writes that "the transport which one attains by the method of the Sufis is like an immediate perception, as if one touched the objects with one's hand" (quoted in James 1902/2002, 314). Al-Ghazālī then goes on to point out an implication of this fact about the nature of ('mystical') experience that could be used as a basis for arguing against James, for the rationality of beliefs based on ('mystical') experience. Al-Ghazālī writes:

[2] If you were to tell a man who was himself without experience of [sleep] that there are people who... resemble dead men... he would deny it [and give his reasons]. Nevertheless, his arguments would be refuted by actual experience. (Quoted in James 1902/2002, 313)

Someone who has not experienced sleep may conceivably be able to come up with a discursively communicable, philosophical argument for why one should not believe that sleep exists. At least in principle, that argument could even be "rational" in the sense that it could (at least hypothetically) be constructed in a way where it validly deduced its conclusion from independently plausible, non-question-begging premises. Someone who believed in the reality of sleep on the basis of her own experience of it, might lack this kind of discursive, deductively valid argument for her belief. Nevertheless, al-Ghazālī challenges us to notice that the sleepless person's argument to the person who had experienced sleep would be rationally refuted by the latter's actual experience of sleep. After all, what better rational basis could that latter person want for believing in the existence of sleep, than their own direct experience of being asleep? Though the experiential nature of the grounds for someone's belief in sleep

\footnotetext{
${ }^{16}$ James does mention that even if some people have mystical experiences, that provides "no logical force" for others to accept their testimony. However, he doesn't explain whether or how this feature of mystical experience sets it apart from ordinary sensuous experience. It would seem that the fact that most of us (say) see some words on a page before us as we read this would provide rational recommendation to others for believing that those words on this page existed. So James still owes us an account of why things are different with mystical experience. For further discussion of the similarities and differences between these cases, see Mawson 2005, 163ff.
} 
may be "ineffable" and "incommunicable", thus, this ineffability and incommunicability of experience does not necessarily seem to undermine the rationality of the beliefs based on it. Similarly, al-Ghazālī's argument seems to be intended to show, the ineffability and incommunicability of (so called) 'mystical' experience should not be regarded as grounds to deny that such experience can serve as a rational avenue to knowledge.

Judging by the lights of scholars of religion like Renan and James, al-Ghazālī's emphasis on the primacy of experience as a route to knowledge may not only qualify him as a "mystic", but also disqualify him from being properly regarded as someone who cares about the importance of human beings' powers of rationality. However, we've seen that once al-Ghazāli is taken seriously on his own terms, he cannot be so easily assumed to belong to the ranks of the "anti-rationalists". To follow James and Renan in placing him in that category simply because he puts greater emphasis on experiential rather than philosophical avenues to knowledge is thus to impose on him an alien dichotomy between 'mysticism' and 'rationality' that risks distorting his views.

\section{AL-GHAZĀLI AS PHILOSOPHICAL RATIONALITIST}

After discussing the shortcomings of Western approaches to scholarship that subordinate "mystical" insight to "rational" knowledge, King goes on in Orientalism and Religion to critique an alternative approach that flips this hierarchy and instead insists that the deliverances of 'rational' philosophical argumentation should be subordinated to those of 'mystical' experience. King objects to this approach, sinceas he points out - it "inverts" rather than "transcend[s]" the dichotomy between 'mysticism' and 'rationality' that Western scholars have constructed $(1999,28)$. Because this approach persists in assuming a dichotomy between 'mysticism' and 'rationality', King worries that it threatens to continue to distort scholarly discussions of Eastern thinkers work.

Though recent scholarship on al-Ghazāli is not guilty of the precise inversion that King discusses, it commits a related inversion in the interpretation of al-Ghazālī's work that similarly fails to transcend the dichotomy between the categories of 'mysticism' and 'rationality'. Rather than inverting the traditional hierarchy between these categories, several contemporary scholars have instead tried to flip conventional interpretations of al-Ghazālî's work so as to relocate his place within the hierarchy. Thus, authors like Richard Frank (1987, 1994), Taneli Kukkonen (2015), and Alexander Treiger (2008) have argued that-despite appearances to the contrary-alGhazālî̀'s noetics is fundamentally the same as that of his more philosophicallyoriented, Aristotelian predecessor Ibn Sīnā. ${ }^{17}$ Although al-Ghazālī often talks about experiential knowledge and locates the source of that knowledge in the "heart", these scholars argue that al-Ghazâlī's fundamental noetic commitments are best understood

\footnotetext{
${ }^{17}$ For discussion of Ibn Sīnā as working in the Aristotelian tradition, see Gutas 2014.
} 
by reference to Ibn Sīnā's conception of the "rational soul"18 — a conception of the soul that lays emphasis on our capacity for conceptual understanding and for the kinds of deductive, syllogistic argumentation that such understanding makes possible. ${ }^{19}$ Treiger goes the furthest, claiming that al-Ghazāli uses talk of the experiences of the "heart" merely as a façon de parler. In using such "heart" language, Treiger argues, al-Ghazāli "did not intend any radical departure from this philosophical noetics in the direction of a more 'emotional' noetics of the heart"; rather, he claims, al-Ghazāli used that language to "defuse" the philosophical connotations associated with concept of the "rational soul" in an effort to make his ideas more "palatable" to the religious scholars of his time $(2008,18)$.

In this section, I critique several of Treiger's arguments for claiming that al-Ghazāli appropriated Ibn Sīnā's conception of the "rational soul". ${ }^{20}$ I conclude that just as alGhazālî̀'s noetics can't easily be fit into the category non-rational mysticism that Renan and James try to fit it into, it also can't appropriately be understood in terms of this category of philosophical rationality that is often assumed to provide a counterposing alternative to mysticism. This negative conclusion sets the stage for my more positive argument in the next section, where I show how al-Ghazāli transcends the dichotomy between 'mysticism' and 'rationality' by drawing attention to the rational merits of (so called) 'mystical' experience.

Like the arguments of other Western scholars who King (1999) critiques, ${ }^{21}$ Treiger's arguments for identifying al-Ghazālī's "heart" with Ibn Sīnā's "rational soul" often depend on a simplified, homogenized conception of the 'mystical' tradition at stake in his study - that is, in his case, the Sufi tradition. First, Treiger points out that, just as al-Ghazālī describes the heart as a "mirror" which reflects the "real nature of the thing sought in religion" so also Ibn Sīnā describes the rational soul as a "mirror" upon which "the forms of things become impressed" (quoted in Treiger 2012, 62). Treiger not only claims that al-Ghazāli gets this analogy of the mirror from Ibn Sīnā, but also argues that his decision to follow Ibn Sīnā in using this analogy is evidence of his shift away from Sufi mysticism. ${ }^{22}$ He points out that Sufis like al-Hallaj and al-Bistami had pantheistic views that led them to claim to enjoy a kind of mystical union with God in

\footnotetext{
${ }^{18}$ Kukkonen (2015) writes of the "full-scale adoption on al-Ghazālī's part of Ibn Sīnā's philosophical psychology" (162; see also 2008, 217). Frank (1994) argues that though al-Ghazāli "assiduously avoids the use of their language", al-Ghazâlī's "conception of the nature and operation of the mind is fundamentally that of the falasifa" [25; see also Frank 1987].

${ }^{19}$ See e.g., Treiger 2008, 18 and Gutas 2016.

${ }^{20}$ I focus on Treiger because he gives the most extended argument for the relevant claims identifying alGhazli's "heart" with Ibn Sīnā's "rational soul". I will not be able to take on a full study of Treiger's arguments but will focus on three important elements of his argument that are discussed in Chapters 1 and 4 of his Inspired Knowledge in Islamic Thought. Treiger's primary attention is on al-Ghazālī's magnum opus, the Revival of Religious Sciences, and I too will focus on that text.

${ }^{21}$ For more on this, see King 1999, 23-25, 185.

${ }^{22}$ In addition to making the point about the pantheistic views of al-Hallaj and al-Bistami that I discuss in the main text, Treiger also argues that the representation of the heart as a polished mirror "seems absent" from the classical Sufi tradition" $(2012,44)$. As we see with the examples I cite in the next paragraph, this is not the case.
} 
moments of ecstatic mystical experience. By analogizing the heart to a mirror that merely reflects, rather than being at one with, an external reality, Treiger argues, alGhazālī would have been distancing himself from these pantheistic Sufi views (2012, 43). ${ }^{23}$

While Treiger is right to point out that al-Ghazālī and Ibn Sīnā both used the image of a reflection in a mirror as an analogy for knowledge, he is wrong to think that the use of this analogy serves as any indication that al-Ghazāli had a preference for Ibn Sīnā's more philosophically-oriented noetics over that of the Sufi tradition. For, even if al-Hallaj and al-Bastimi had pantheistically-inclined conceptions of our connection to God, there are a great many Sufi's who didn't, and who - like al-Ghazālī-used the analogy of the mirror to make their point about human knowledge of God. For instance, Harith al-Muhāsibī discusses knowledge of God in terms of contemplation rather than ecstatic union, and he argues - as we will see in the next section that al-Ghazāli also does - that it is only when one is willing to undergo the discipline of "polishing" the "mirror" of the heart, that one gains experiential knowledge of God (Renard 2004, 21). Along the same lines, Abu Talib al-Makkī discusses knowledge of God in terms of seeing the "vision of [God's] Face" in the mirror of the heart and writes that the heart is "likened to [a] mirror" that reflects "treasuries of the Hidden" (Yazeki 2013, 68, 73). Al-Ghazālī explicitly cites al-Muhāsibī and al-Makkī as influences, ${ }^{24}$ and so there is little reason to think that his use of the analogy of the mirror indicates any attempt on his part to move away from the "mystical" Sufi tradition.

A similar critique can also be advanced against another plank of Treiger's argument, which emphasizes that both al-Ghazālî̀s "heart" and Ibn Sīnā's "rational soul" are immortal and immaterial. Treiger argues that, just as Ibn Sīnā conceived of the rational soul as a non-material entity that, in the hereafter, departs from the body to either enjoy "felicity and pleasure" or to suffer "misery and pain", so also al-Ghazāli thought of the heart as a non-material entity connected to the body that is released, in the hereafter, to a state of heavenly bliss or hellish suffering $(2012,17-18) .{ }^{25}$

As with the previous argument concerning al-Ghazālī's understanding of the heart

\footnotetext{
${ }^{23}$ In making this argument, Treiger follows the work of W.H.T. Gairdner (1914).

${ }^{24}$ For al-Makkī, see Yazeki 2013, 99 and Nakamura (1984). For Muhāsibī see Al-Ghazālī, The Book of Knowledge (1962, transl. Faris), 218.

${ }^{25}$ The fact that both al-Ghazālî̀s "heart" and Ibn Sinnā's "rational soul" are supposed to be immaterial and immortal is not by itself very strong evidence for Treiger's claim that al-Ghazālī directly appropriated his concept of the heart from Ibn Sīnā's concept of the rational soul. Still, there's more to be said for Treiger's contention here than he himself explicitly advances. A consideration that may have been in the back of his mind, and may play some role in motivating his argument, is that in claiming that the heart was immortal and immaterial al-Ghazāli would have been distancing himself from one major alternative to Avicennic noetics: that of the Asharites, who treated the soul as a kind of corporeal principle (albeit a special one; see Kukkonen 2008, 207; for more on the dynamic between al-Ghazâlī, the Asharites, and the philosophers on this point see Griffel 2009, 285). Al-Ghazālī's distancing himself from a major alternative to Avicennan noetics could be understood as an attempt to hook onto an Avicennan noetics. What's more, perhaps having distanced himself somewhat from the Asharite's theological take on psychology, al-Ghazālī may have been eager not to appear too un-theological, and so (as Treiger says) al-Ghazālì may have chosen heart-related language to make his work more palatable to religious scholars.
} 
as a mirror, this argument concerning al-Ghazālī's understanding of the heart as immaterial and immaterial only gets the traction Treiger wants it to if one does not pay close attention to the Sufi tradition al-Ghazāli himself explicitly claims allegiance to. ${ }^{26}$ For-like with al-Ghazālī's discussions about the "mirror" of the heart—al-Ghazālī's position on these matters concerning the immateriality and immortality of the heart can just as well be understood to fall in line with the Sufi tradition as with Ibn Sinnā's more traditional philosophical alternative. Al-Makkī, for instance, seems to appeal to a duality between body and soul when he distinguishes the heart, as an "internal" tool, from the body, which serves as an "external" tool (Yazeki 2013, 52), and Al-Muhāsibī appears to do the same when he argues that the heart operates in an "inner" sphere that is the origin of the "external" actions of the body (Yazeki 2013, 37). Al-Muhāsibī is also clear that the human soul must separate from the body in order to enter an immortal afterlife. Thus, he writes that:

The angels come to the dead person [upon death] and if he was righteous they say, 'Exit O good soul that was in a good body; exit nobly and receive glad tidings of repose... If [however] he was wicked they say, 'Exit $\mathrm{O}$ despicable soul... Exit in disdain and receive tidings of scalding.' (Picken 2011, 145)

Since there is already a clear precedent within the Sufi tradition for understanding the soul as immortal and immaterial, there is little reason to think that al-Ghazālī's claims about the immortality and immateriality of the "heart" indicate any preference for Ibn Sinnā's philosophical noetics over the more ('mystical') experiential noetics of the Sufis.

A third argument that Treiger advances in favor of identifying al-Ghazālî's "heart" with Ibn Sīnā's "rational soul" is more successful in showing that al-Ghazālī has some unique debts to Ibn Sīnā-but it still fails to establish that al-Ghazālī does not also make a more fundamental shift in favor of the experience-based, 'mystical' modes of knowing associated with the Sufis. To try to show that al-Ghazālì's "heart" can be identified with Ibn Sīnā's "rational soul", Treiger points out various parallels between Ibn Sinnā's understanding of the stages of intellectual development that the "rational soul" progresses through, and al-Ghazālì's understanding of the stages of intellectual development that the "heart" progresses through. In particular, Treiger argues that alGhazālī closely follows Ibn Sinna in tracing the maturation of the "heart" through three stages of development that Ibn Sīnā had previously described the "rational soul" as undergoing: first, the stage of what Ibn Sinnā called the material intellect, which represents our pure potentiality for knowledge; second, the stage of what Ibn Sinā called the intellect in habitu, in which the soul gains the kind of axiomatic, a priori concepts that are needed in order for it to later be in a position to perform syllogistic reasoning; and third and finally, the stage of what Ibn Sinna called the actual intellect, in which the intellect not only acquires facility with a broad range of concepts, but also, in virtue of its possession of these concepts, is able to perform syllogistic reasoning so as to acquire deductively-valid knowledge on a wide variety of issues.

${ }^{26}$ Kukkonen $(2012,543)$ seems to agree with me on this point. 
While there are several minor complaints that one might lodge about Treiger's argument as described so far (in which he compares the first three stages of development of the "heart" with the three stages of development of the "rational soul"), ${ }^{27}$ the primary problem with his argument is that it does not adequately account for the importance of a further, fourth stage of development of the "heart" that alGhazālī adds, that is not present in Ibn Sīnā's discussion of the development of the "rational soul". Al-Ghazālī describes this stage as follows:

[2] The power of instinct... [develops] to the extent that its owner will be able to tell what the end will be [or, in Treiger's translation, "to cognize the outcomes of things"], and consequently will conquer and subdue his appetite which hankers for immediate pleasure. Whenever such a power obtains, its owner, in view of the fact that he embarks upon an undertaking or refrains from it only after a thorough consideration of its end, is called intelligent. $(1962,219)$

This stage of development is not only left out of Ibn Sīnā's three-part account of the development of the "rational soul", it is also clearly regarded by al-Ghazāli as the most important and highest stage of intellectual development of the "heart"-indeed, he says it is the "final fruit and ultimate aim" of all the other stages $(1962,219)$. The fact that al-Ghazālī adds this stage of development to the "heart" that is not present in Ibn Sīnā's discussion of the "rational soul" is strong prima facie evidence that he means to push beyond Ibn Sīnā's neotic framework. Moreover, by the end of this section, we will see that al-Ghazālī is not only pushing away from Ibn Sīnā's noetic framework but is also specifically pulling himself towards the framework for gaining experiential knowledge that is provided by the ('mystical') Sufi tradition.

Treiger recognizes the problem I have just drawn attention to and tries to address it, but his response is not successful in vindicating his conclusion that al-Ghazālī's conception of the "heart" is essentially the same as Ibn Sīnā's conception of the "rational soul". Treiger argues that this fourth, highest stage of intellectual achievement that al-Ghazālī refers to does not constitute a significant departure from Ibn Sīnā because al-Ghazāli is actually merely "superadd[ing]" another element of Ibn Sīnā's noetics: that of the "sacred" or "prophetic" intellect $(2012,25)$. In fact, however, there are extremely important differences between the fourth stage of the intellectual development of the "heart" - let's call it, the stage of the fully developed intellect - and Ibn Sīnā's prophetic intellect.

For Ibn Sinā, the prophetic intellect is marked by its ability to move from the intellect in habitu (the second stage of development, where a person only has the most basic axiomatic concepts) to the actual intellect (the third stage of development, where

\footnotetext{
${ }^{27}$ There are at least two complaints one might lodge against Treiger's analysis thus far. First, in taking about the first stage of knowledge - the stage of "instinct"-al-Ghazāli explicitly appeals to al-Muhāsibī as his influence, and so he need not be seen as simply appropriating Ibn Sīnā's thought there $(1962,218)$. Al-Makkī also discusses an inborn "impulse" to reason (see Yazeki 2013, 73.). Second, at the third stage of knowledge, where Ibn Sīnā specifically emphasizes acquisition of concepts that can support broadranging syllogistic reasoning, al-Ghazālī does not. Instead, al-Ghazālī focuses on a posteriori knowledge more generally $(1962,219)$.
} 
a person gains a broad range of concepts that allows him to reason syllogistically about a wide variety of topics) via an especially strong form of intuitive power called hads. Given this power of hads, those with a prophetic intellect do not need to go through any arduous process to acquire the variety of concepts needed for robust, wide-ranging syllogistic reasoning; instead, they can simply and effortlessly intuit the content of these concepts (Treiger 2012, 76). Treiger acknowledges that al-Ghazālī does not ever refer to hads in his own voice in authenticated works, ${ }^{28}$ but Treiger nevertheless defends the identification of al-Ghazālī's fully developed "heart" with Ibn Sīnā's "prophetic intellect" by claiming that al-Ghazālī's reference to "cognition of the outcome of things" in his description of the fully developed "heart" is a "vague expression" for prophecy $(2012,24) .{ }^{29}$ However, this defense is implausible. To begin, notice that al-Ghazāli does not seem to think of the fully developed intellect as one which simply has a generalized premonition of 'things to come'; 30 instead, what he seems to be most concerned emphasize is the practical competences with which the fully developed intellect provides its possessor. For he suggests that the person with a fully developed intellect is one that can present "cognize the outcomes of things" in a way that allows the owner to "conquer and subdue his appetite" and to "refrain from [immediate pleasure]" (see passage [2] above; 1962, 219); moreover, al-Ghazālī points out that such a person is called "intelligent" for how he is able to choose to undertake, or not to undertake, actions in light of his understanding of the outcomes of those actions. The person with a fully developed intellect, in other words, has a kind of practical intelligence that allows her to appreciate what the good or bad outcomes of her choices will be in a manner that is specifically well-suited to motivate her to act properly in accordance with what is required to get the right outcomes.

\footnotetext{
${ }^{28}$ He uses it only when talking about the philosopher's doctrines (see Treiger 2012, 77).

${ }^{29} \mathrm{He}$ also points out that, like Ibn Sīnā, al-Ghazāli describes prophetic inspiration as being effortless; for instance, he points out that al-Ghazāli writes that for prophets, "obscure matters become clear... without learning or instruction" (Treiger 2012, 78). Even if al-Ghazālī and Ibn Sīnā share a conception of prophetic inspiration, however, this does not yet indicate anything about whether al-Ghazālī identifies his fully developed intellect just or specifically with the one who is prophetically inspired. Additionally, Treiger points to a passage in the Niche of Lights where al-Ghazālī speaks of a "reflective spirit" that can be subdivided into two kinds, one that requires "instruction, awakening, and help from the outside" and one that does not $(2012,75)$. Treiger argues that, just as Ibn Sinnā's prophetic intellect might be understood as a "higher" version of his third stage of intellectual development (the stage of the actual intellect, which has acquired broad-ranging facility with the concepts required to support syllogistic argumentation) so also al-Ghazālī's fully developed intellect can be seen as constituting a "higher" version of his third stage of development (where that stage is, according to Treiger, itself the equivalent of Ibn Sīnā's "actual intellect"). However, when al-Ghazāli discusses the "reflective spirit", he does not do so in the context of stages of intellectual development, and so it is not clear what (if any) stage in that development he takes this "reflective spirit" to correspond to. More importantly, even if there are two kinds of "reflective spirits", this could very well just indicate that people possess the "actual intellect" in different ways; it says nothing about the relation of that "reflective spirit" to al-Ghazālī's fourth stage of intellectual development.

${ }^{30}$ It is also worth noting that, even if he did think of the fully developed intellect as one which has a generalized premonition of things to come, it's not clear how that would relate to Ibn Sinna's prophetic power of hads, the distinguishing feature of which is its capacity to intuit the content of concepts (see, e.g., Treiger 2012, 76).
} 
This kind of power of practical intelligence is one that al-Ghazāli frequently discusses in other contexts that don't appear to have anything to do with prophetic insight as such and instead seem to be focused on the kind of powers of practical selfgovernance that all people are enjoined to exercise. Thus, for instance, consider again the following passage I alluded to in the last section, which takes place in the middle of one of al-Ghazālî's general discussions about the nature of the intellect, i.e., of the "heart":

[3] The intellect is like a horseman who has gone hunting. His appetence is his horse and his anger is his dog. When the horseman is skilled... he is able to succeed. But when he is himself clumsy... then his horse is neither guided under him, nor does his dog go forth in obedience to his signs... The clumsiness of the horseman is like the ignorance of a man... and his dim insight. $(1977,23)$

In this and other passages like it, al-Ghazālī seems to have in mind the same kind of power of practical intelligence that he attributes to the person with a fully developed intellect: what is distinctive of this intellect is that it is able to use its cognitions to correctly regulate action in a way that will, in turn, allow a person to reach relevant desired outcomes (i.e., to succeed in the 'hunt'). But in this and the other passages in which al-Ghazālī uses similar metaphors, he nowhere indicates that only prophets have the kind of practically-efficacious cognition he is describing. ${ }^{31}$ To the contrary, in these passages, al-Ghazālī seems to lay out a quite general picture of how a fully developed human intellect should properly function.

The final and strongest reason to doubt that al-Ghazālī's fully developed "heart" can be identified with Ibn Sīnā's "prophetic" intellect is that al-Ghazālī pretty clearly seems to think that the kind of practically-efficacious knowledge that the fully developed intellect has-let's call it, supreme knowledge-is the kind of experiential knowledge that the ('mystical') Sufi tradition gives people access to. Moreover, alGhazāli goes to great pains to distinguish this kind of experiential knowledge from the more purely theoretical knowledge of concepts that is supplied by Ibn Sīnā's prophetic power of hads.

First, al-Ghazāli is clear that he thinks that it is the Sufis who provide the best exemplars of those who have fully developed, practically-efficacious intellects. It is they, he points out, who are most distinguished for having the kind of knowledge that "takes hold of" and "prevails over the heart", so that it can as a result "[become] the ruler... of the soul either by urging it to action or by forbidding it therefrom" (1962, 188). Al-Ghazāli also demonstrates the practical efficaciousness of Sufis' knowledge by making specific reference to an analogy that involves "tell[ing] what the end will be" (as mentioned in his description of the fully developed intellect; see passage [2]): he suggests that the difference between the kind of knowledge that the Sufis have and other, lesser kinds of knowledge is illustrated by difference between people who know their lives will end in death, and appreciate the significance of this fact in a way that

${ }^{31}$ See footnote 9 for references to similar passages. 
motivates them to prepare for death, and people who know their lives will end in death, but fail to appreciate that fact in a way that has any effect on their life $(1962,188)$.

Besides making clear that it is the Sufis who possess the kind of practically efficacious knowledge that he associates with the fully developed intellect, al-Ghazâli is also clear about a second feature of this kind of knowledge: that is, that it involves a direct experiential presentation of its object. While those who believe by blind acceptance are like those who believe that a person, "Zayd", is in a house on the basis of testimony (57-58), and while those who have belief "mingled with proof" are like those who believe Zayd is in a house on the basis of deduction from the sound of his voice behind a wall (58-59), al-Ghazālī says that the Sufis are like the person who "enter[s] the house and look[s] at him with [his] own eyes and see him" (1977, 59-60). Only they, he writes, have the kind of "real experiential knowledge" that comes from being an eyewitness to something (59).

In the next section, I will show how the experiential component of supreme knowledge connects to its practical efficaciousness. For the moment, however, it is important to point out how the prophetic power of hads (as Ibn Sīnā conceives of it) does not appear to be at all well-suited to play this kind of practical psychological role that al-Ghazālī has in mind for supreme knowledge to play. As discussed previously, hads involves cognition into the nature of an abstract concept; in particular, it involves that kind of cognition of a concept that is needed for to be able to employ it in syllogistic reasoning. But this kind of insight into the abstract nature of a concept does not seem, on al-Ghazālī's view, to be able to have the kind of practical motivational force that he associates with cognition at the fourth stage of the development of the "heart". To the contrary, al-Ghazālī frequently emphasizes the difference between merely understanding a concept and being motivationally affected by the underlying reality it refers to. Consider for instance the important passage cited in Section 1, in which alGhazāli points to the difference between "knowing the definitions of health... and being really healthy", and between "know[ing] in what drunkenness consists and being drunk effectively". Just as knowing what drunkenness (or health) consists is not apt to provide the motivational basis for acting in a drunken (or healthy) way, so also more generally, knowing the content of a concept does not in itself necessarily do much to incline one to act in accordance with the underlying reality it refers to. The person whose heart has developed to the fourth stage, thus, does not seem to be someone who stands out for her ability to grasp abstract concepts with ease and acuity-as the person with the prophet power of hads would. Rather, the person with the fully developed intellect seems to be distinguished by the fact that she (i) possesses a kind of understanding of the evaluative significance of those objects that, in turn, allows her to effectively align her practical conduct with her knowledge, and (ii) has an experiential grasp of relevant objects of knowledge. ${ }^{32}$

\footnotetext{
${ }^{32}$ In thus exalting the importance of practical efficaciousness knowledge, al-Ghazālī once again appears to be staying true to the mystical Sufi tradition that he explicitly champions: The emphasis on praxis over theory is also emphasized by, for instance, al-Muhāsibī and al-Makkī (Renard 2004, 21-22, 36-37).
} 


\section{AL-GHAZĀLI ON THE REASONS OF THE HEART}

In the last two sections, I have shown that al-Ghazālī's views about the experiential knowledge of the heart neither align with Renan and James's assumptions about the non-rational nature of 'mystical' experience, nor fit within the noetic framework that Ibn Sīnā associates with the "rational soul". While my argument thus far has been largely negative - aimed to show how al-Ghazālī's thought cannot easily be made sense of in terms of the categories of 'mysticism' and 'rationality' that others have imposed on him - in this section I focus on a more positive task. In particular, I show how alGhazāli anticipated insights about the rational merits of experiential forms of cognition that contemporary psychologists and philosophers of emotion have only recently begun to appreciate.

\subsection{EXPERIENTIAL KNOWLEDGE AND RATIONAL ACTION}

In the last section, I argued against Treiger's claim that al-Ghazālī's supreme knowledge could be identified with Ibn Sinnā's prophetic insight on the grounds that (i) the former appears to play a general role in motivating practical action (for prophets and non-prophets alike), whereas the latter is specifically reserved for prophets and (ii) the former is experiential in a way that the latter is not. In fact, it turns out that these two features of al-Ghazālī's supreme knowledge are intimately connected: one lesson that al-Ghazāli teaches us about experiential knowledge is that it plays a unique and critical role in underwriting our motivation to act rationally in alignment with our practical goals.

Recall that at the third level of intellectual development, which Treiger argues that Ibn Sīnā and al-Ghazālī both agree about, a person develops a facility with a broad range of concepts that, in turn, allows her to gain knowledge by way of syllogistic deduction. It is significant that al-Ghazāli sees an intellect that has only progressed to this third stage as not fully developed. By highlighting that the fourth stage of development is the "final fruit and ultimate aim" of all the other stages, al-Ghazāli encourages us to consider the rational defectiveness of an intellect that stopped short of this fourth stage-e.g., an intellect that achieves deductive, conceptual knowledge of the results of a person's actions, but has nevertheless not yet learned to connect that conceptual knowledge to the person's larger system of practical motivation in a way that allows her to actually use that knowledge to effectively prompt rational decisionmaking.

Antonio Damasio, a contemporary professor of psychology whose ideas about the importance of experiential cognition (we will soon see) al-Ghazālī seems to have anticipated, gives an example that helps illustrate al-Ghazālī's point. Damasio writes of a subject, who he calls "Elliot", who came to him to get certification for disability benefits after undergoing a brain surgery that removed frontal lobe tissue important to the processing of emotions and feeling (1991, 34ff). Elliot had had difficulty getting such certification from others because (as Damasio notes) he in many respects had a 
"superior intellect" (41). In addition to getting superior results on various subtests of the Wechsler Adult Intelligence Scale (41), he achieved above average results in experimental tasks that tested his awareness of, and ability to explain, the consequences of his actions (47), and performed "impeccably" on tests assessing his ability to conceptualize effective means for achieving successful outcomes (47). Despite all this - and despite the fact that, before the brain surgery, Elliot had been a responsible and successful employee (35) ${ }^{33}$-Elliot had been fired from his job because he could no longer be relied on to carry out tasks or effectively complete the projects that were assigned to him $(34,36-38)$. When he was assigned to produce a particular outcome, he would easily become side-tracked in irrelevant details (e.g. should documents be listed by date or size?), or would jump between different tasks in a way that prevented him from making any real progress on the overall goals at hand (36-37). Though Elliot may (it seems) have retained the kind of conceptual and deductive powers that Ibn Sinnā assigns to his third (and final) stage of intellectual development (i.e. the stage of the "actual intellect")_-Elliot's case shows how one who has not yet gained the kind of powers of practical intelligence that al-Ghazāli associates with the fully developed intellect will tend to fail to appropriately act on the reasons he takes himself to have (in the abstract), and in this respect fail to be fully rational.

Beyond just pushing us to recognize that an intellect that has not yet learned to integrate theoretical knowledge with practical action is in some respects not yet fully developed, Al-Ghazālī also offers insight into why experiential knowledge plays a critical role in supporting that needed integration. Making reference to a kind of "certainty" and "faith" that he elsewhere describes in experiential terms, ${ }^{34}$ al-Ghazālī writes:

[4] When a man's certainty is strengthened - I mean by this the knowledge that is called faith - [this certainty is] certainty that the appetite is an enemy... [This] power of knowledge and faith... makes the evil consequences of the appetite appear odious. (2011, 15-16; my emphasis)

Here, al-Ghazālī suggests that experiential knowledge can motivate us to avoid evaluatively bad outcomes because it can present knowledge of those outcomes in a particular, phenomenologically charged way. A person who represents consequence of action as "evil" in a purely abstract, conceptual way will plausibly need to rely on some further, external motivational power to operate on that abstract presentation so as to spur action. However, consequences that are presented to a person as "evil" in an experiential way can build into that presentation of evil, a presentation of evil as odious,

\footnotetext{
${ }^{33} \mathrm{He}$ had also been described as a good husband and father, and a role model for colleagues and siblings (35).

${ }^{34}$ In The Marvels of the Heart (1977), al-Ghazālī discusses "three degrees" of faith; the third degree of faith is the faith that "is seeing clearly with the light of certainty", and this is the "faith of the mystics" (57). Later in the same passage, al-Ghazāli discusses the example of the three ways of coming to know that "Zayd" is in a house, an example I discussed in Section 2.
} 
and thus as undesirable and as to be avoided. ${ }^{35}$ Since an experiential presentation of the outcomes of one's actions can be phenomenologically "charged" in this way, knowledge based on experience is plausibly poised to "jump-start" someone's engines of motivation in a way that pure conceptual knowledge would not be. This, in turn, means that experiential knowledge can serve to rationally integrate what a person knows within a larger system of rational action, in a way that purely conceptual knowledge would (it seems) not be equally effective at doing.

To get a further intuition of what al-Ghazālī may be after here in highlighting the experiential component of practically efficacious knowledge, consider this example that philosopher Michael Stocker (1983) provides in the course of critiquing contemporary philosophical psychologists for their failure to appreciate the importance of (what he terms) "psychic feelings". Stocker asks us to imagine the difference between knowing that walking on ice is dangerous before and after a nasty fall on the ice. Before the fall one may have a purely intellectual representation of the danger of walking on the ice, and this (he points out) may give rise, at best, to a "rather pro-forma desire" to avoid that danger (153). Though you may formally desire to avoid putting yourself in a dangerous position, your merely intellectual understanding of the danger of walking on ice may cause you be incautious and to take risks with the ice that are not aligned with the reasons you (abstractly) know you have not to take. After the fall, however, Stocker notes, the dangers of walking on ice are experientially present to you-you "feel" the dangers, rather than just knowing of them-and so become viscerally concerned about those dangers (20-21). ${ }^{36}$ With this experiential knowledge of the dangers of walking on ice now in hand, you will plausibly be better positioned to act in accord with the practical reasons you have to walk on the ice in one manner rather than another: because, as al-Ghazāli suggests (in passage [4]), the "evil consequences" of walking on ice now "appear odious" to you, you will be in a better position to be motivated to act with the amount of caution and care that the situation actually calls for. It is because experiential knowledge presents its object in this phenomenologically-charged way that - as the old adage goes - "experience is the best teacher"; experiential knowledge is well-suited to motivate practical action in a way that conceptual and deductive knowledge (of the sort Ibn Sinnā assigns to the actual intellect and the prophet's power of hads) seems ill-fit to do.

Al-Ghazālī's insight about the importance of experiential knowledge to practical rationality also anticipates the psychological diagnosis that Damasio gives for Elliota conclusion that, it bears noting, Damasio regarded as a new insight in the context of the psychological research programs of his time, which focused on behavioristic and computational models of the mind (1994, ix-x). Damasio argues that it is the "coldbloodedness" of Elliot's reasoning-i.e., the lack of experienced feeling associated with the representations of means and ends in his practical reasoning - that caused him

${ }^{35}$ For more discussion of the content of this kind of phenomenal representation see Coetsee 2020 and Siegel 2014.

${ }^{36}$ Here, your experiential knowledge of the danger of walking on ice will, as al-Ghazālī puts it in passage [4], make the "evil consequences" of doing so "appear odious". 
to act in the erratic and irrational ways that he did (51). ${ }^{37}$ According to Damasio, Elliot's incapacity to (e.g.) represent the outcomes of a project his employer tasked him to pursue in a felt positive light prevented him from being able to assign value to those outcomes in the way that could motivate him to keep his attention on them. This, in turn (Damasio argues), undermined Elliot's ability to be follow through with subtasks in a way that efficiently ordered them towards the achievement of his overall goal (51). Al-Ghazāli seems to want to teach his readers that those who, like Elliot, lack an experiential cognition of the goodness or badness of the outcomes they pursue will be "clumsy" in their "hunt" to achieve their practical goals ([3]; 1977, 23). In this way, alGhazālī also helps us to see certain important rational merits to 'mystical' experience: insofar as 'mystical' experience makes experientially present to people (e.g.) the goodness of God, or the badness of an eternity outside of God's presence, that would (al-Ghazālī shows) contribute to-rather than undermine - their capacity to act as the "rational animals" that Aristotelian philosophers have always envisioned people to be. ${ }^{38}$

\subsection{EXPERIENTIAL KNOWLEDGE AND EVALUATIVE INSIGHT}

Al-Ghazālī also draws our attention to a second way in which experiential knowledge is critical to the operation of human rationality: he highlights how affective experience can play a critical role, not just in motivating action, but also in underwriting persons' full understanding of the evaluative features of the value-laden realities that confront them. ${ }^{39}$ According to al-Ghazālī, the way that the "mirror" of the heart is able to come to gain religious knowledge - or, as he puts it, to "reveal... the real nature of the thing sought in religion"-is by way of being "polished" by virtuous action (1993a, 15). ${ }^{40}$ Moreover, al-Ghazālī characterizes the development of virtue in part in affective terms; according to al-Ghazālī, part of what it is for a person to develop virtue is for her to become habituated to find pleasure in good things. He writes:

[5] If anybody wishes to acquire the virtue of benevolence, he must be habituated to make charity inspite of his unwillingness to spend money... Then it will become easy after place of time. He who finds pleasure in charity is called a philanthropist. $(1993 \mathrm{~b}, 53)$

\footnotetext{
${ }^{37}$ Damasio's discussion of the core elements of his view-which he terms the "somatic-marker hypothesis"- occurs in chapter eight of his book (1994).

38 See Boyle 2012, 399.

${ }^{39}$ This view is also hinted at by Damasio (1994, 51), but he does not discuss it at length.

40 This is from Karim's translation of The Marvels of the Heart (1993). Skellie (1977) translates it slightly differently: "The heart is a mirror which is polished by praiseworthy action... so that there is revealed in it the real nature of the thing sought in religion; but it is tarnished and rusted by blameworthy action so that good is not perceived" (30). Al-Ghazāli continues along these lines: "All of this is an indication that the light of knowledge is not veiled from men's hearts by a stinginess or prohibition on the part of the Giver... but rather is it [sic] veiled by wickedness, uncleanness, and anxiety within the heart. For hearts are like vessels; as long as they are filled with water air cannot enter them. So the knowledge of the majesty of Allah cannot enter into hearts which are occupied with anything else apart from Him" (1977, 30). For related discussion, see Chapter 6 of The Marvels of the Heart (1977, 46-53).
} 
To acquire $[\text { felicity }]^{41} \ldots$ it is not sufficient to hate sins. He must find pleasure in doing good deeds. (1993b, 53)

One should grow habits of doing good deeds. If they are done for long... pleasure will come as a matter of course. $(1993 b, 54)$

If, as al-Ghazālī suggests, virtue consists partially in learning to feel certain ways about the good actions we are enjoined to undertake, and if (as we saw above) al-Ghazāli also holds that such virtue is necessary to "polish" the mirror of the heart to the point that it can successfully "reflect" the "real nature" of the good(s) sought in religion, then it seems to follow that al-Ghazālī thinks that affective experience not only serves to practically motivate rational action, but also that it can actually help make possible a kind of understanding insight into the reality of (e.g.) the good(s) sought in religion, that would not be possible absent such experience. ${ }^{42}$ Al-Ghazālī also suggests a similar intellective role for affective experience elsewhere, when he draws attention to the tight connection between the experience of love of God and knowledge of God. He writes that the "sign" of someone's having genuine experiential knowledge of God is that she loves God, and he suggests that it is only those who love God who truly know Him $(2016,47) .{ }^{43}$ Although we don't normally understand knowledge of a thing as needing to involve any particular kind of affective experience of it, this suggestion that love of God is required for genuine knowledge of God stands in line with the role al-Ghazāli seems to assign to affective experience in "polishing" the mirror of the heart: in both cases, what is at work in producing knowledge of the "real nature" of things is not a disinterested, cognitive perception of them, but rather the a certain kind of affectivelyattuned, experiential presentation of them.

In highlighting the role that affective experience can play in cognition, al-Ghazāli again anticipates an insight about the rational merits of experiential knowledge that Western scholars - in particular, in this case, Western analytic philosophers - have only recently come to appreciate. ${ }^{44}$ In the Western analytic tradition, affective phenomena have often been regarded as forces that can, at best, only properly influence how we react and respond to a world that we should - if we are genuinely rationalperceive on independent, affect-less terms. ${ }^{45}$ While this tradition may leave room open

\footnotetext{
${ }^{41}$ In Karim's translation this word is "fortune", but Winter (2016) translates it as "felicity" (32-33) and this seems more fitting.

${ }^{42}$ Moosa (2005) notes that in late antiquity, the heart was generally seen as being the seat of emotion (224). If, as seems plausible may have been the case, al-Ghazālī picked up on this trend, that gives further evidence for the cognitive importance he assigned to affect.

${ }^{43}$ It is also worth noting that al-Ghazāli thinks that virtue underwrites love of God-its purpose is to "cut off the attachment of the world from soul and to confine [one] to the love of God" (1993b, 53).

${ }^{44}$ By "Western" philosophy, I have in mind primarily Western secular philosophy.

${ }^{45}$ See Dixon (2003) for an excellent overview of the history of the treatment of emotions in Western philosophy. Interestingly, he notes how other religious thinkers like, e.g., Augustine also had an appreciation of the cognitive aspect of religious emotions (26ff). In analytic philosophy, philosophy of mind has long been dominated by the computational theory of mind, which sets aside phenomenological features and instead attempts to account for the minds' operations in functional terms. For classic statements of this view, see Fodor $(1975,1987)$.
} 
for affect to play a dynamic role in spurring rational action, any influence that that affect has in "coloring" our initial perception of reality must (by the view of this tradition) by necessity constitute a rational distortion of that reality. Thus, for instance, even if seeing the world through "rosy colored glasses" might effectively motivate actions that have practical benefits, such an affectively-infused perception of the world must, by virtue of being affectively-infused, in some respect distort the way the world "really is".

Perhaps not coincidentally, given his negative views about the rationality of "mystical" experience, William James (who we considered in the first section) did a great deal to popularize a version of the "non-cognitivist" view about affect I have just described. His position as the (so called) "father" of modern psychology helped popularize his account of emotions as mere "bodily feelings" that do not add any rational, representational content to our perceptions. ${ }^{46}$ Thus, recall his comment that mystical experiences are "excitements, like the emotions... by means of which facts already objectively before us... make a new connection with our active life" (my emphasis; 1902/2002, 334). While James here acknowledges that someone's lack of affective experience might undermine her motivation to act on facts, he seems to deny that such experience could also be essential to her genuinely grasping or understanding the realities underlying those facts - it seems that on his view, relevant realities are always equally cognitively graspable without such experience. ${ }^{47}$

Of course, there may be some affective experiences that function merely as motivational "bodily feelings" of the sort James has in mind. Perhaps, for instance, a brute compulsion to eat a Snickers bar after a long day doing heavy outdoor labor is that way. But as al-Ghazālī seems to have anticipated-and as a growing number of accounts of "cognitive" and "evaluative" emotions discussed by contemporary Western moral philosophers like Linda Zagzebski (2003, 104-24; 2004, 51-95), Martha Nussbaum (1990, 2001), and Robert Solomon $(2003,2007)^{48}$ remind us-many affective experiences carry a much richer representational content than that of the brute compulsion for a Snickers bar; they add a component of cognitive understanding of that which is represented in experience, which would be lost but for that affective element of the experience.

An example inspired by a story from Martha Nussbaum (2001, 19-24) helps illustrate this point. Suppose you read in the morning newspaper that someone has died in a car crash. Though you read a description of the deceased that makes them out to be a wonderful person, you at first cognize the report of their passing in a theoretical and largely affectless way - as just one among many unfortunate events reported in the day's news. Then, however, you find out that the person is a close friend you valued and admired. Now, your experience of the event shifts: you are unsettled and distressed, grief-stricken by the thought of world's being without the person with all the wonderful,

\footnotetext{
${ }^{46}$ For discussion of James's historical influence, see Dixon 2003, Chapters 1 and 7.

${ }^{47}$ For more on James' views, see Dixon 2003, 7 and Deonna and Teroni 2012, Chapter 6.

48 See also Blum 1994.
} 
valuable qualities you experienced her as having. ${ }^{49}$ Nussbaum suggests that it is only after you apprehend the loss in this latter, affectively-mediated way, that you genuinely grasp the moral (dis)value of that loss.

More specifically, Nussbaum argues that it is in virtue of now apprehending the loss of your friend in this affectively-mediated way that you grasp its negative evaluative significance. Nussbaum puts the thought well when she talks about the experience of grieving after a similarly shocking loss of her mother: "when I grieve," she writes, "I do not first of all coolly embrace the position, "My wonderful mother is dead,' and then set about grieving" (45, my emphasis). "No", Nussbaum argues, the "real full recognition" of that loss of value is the affective "upheaval" (45). Similarly, in our example (Nussbaum would argue), you do not genuinely and fully assent to the proposition that 'my dear and valued friend is lost' until you take on and allow yourself to imbibe in the felt experience of that loss. To take one more example of Nussbaum's point, one might compare the emotionally vivid experience of a young soldier in military combat, to that of someone who has been fighting in combat for years and has become numb to it. Plausibly, even though the older soldier knows more about war, in a purely intellectual sense, the younger one-who still experiences war in an emotionally 'alive' way - understands and appreciates something true about the 'hell of war', about the tragedy and deep disvalue that is associated with combat, that the older, emotionally numb soldier has lost touch with. In both cases, contrary to what James would suggest, the evaluative facts about the loss of your friend, or about the 'hell' of war, aren't fully present to the knower prior to their taking an affectivelymediated perspective on those facts. That affectively-mediated experience partially constitutes the knower's full grasp of the evaluative properties before them, i.e., in this case, their moral disvalue.

While al-Ghazālī's discussion of the role that pleasure and love play in underwriting the heart's cognition of the things "sought in religion" (1993a, 15) may initially seem far-fetched to some, we are now in a position to appreciate the insight that that discussion offers. Just as, in the example inspired by Nussbaum, you do not genuinely grasp the moral disvalue of your friend's passing when you merely "coolly embrace[s]" the proposition reported in the news, so also, one might say, we do not genuinely grasp the value of (e.g.) charity - or the goodness of other things God may reveal to a "polished" heart-merely by abstractly, conceptually understanding that being charitable is valuable. Instead, that grasp of the positive value of charity-or other good things revealed in religion-is at least partially constituted by the experience of delight and pleasure that a virtuous person has in reflecting on or undertaking acts of charity. Along the same lines, al-Ghazāli suggests that we do not genuinely grasp (e.g.) the goodness of God when we have a merely conceptual

\footnotetext{
${ }^{49}$ You have two representations of the situation, one of which underwrites an understanding of the evaluative significance of the event, and one which doesn't; moreover, the one that underwrites that understanding is the one that presents the relevant facts in an affectively infused light. On Nussbaum's view, it is by virtue of the fact that the latter representation presents the loss of a person in an affectively infused light that one who has that kind of representation is able to fully and genuinely represents the loss of that person, as a valued someone.
} 
representation of the fact that God is good. As, in the example considered above, the genuine understanding of the moral disvalue of a person's passing is inextricably intertwined with, and underwritten by, the experience of grief at his loss, so also, alGhazāli challenges us to notice, one's genuine understanding of the positive value of God is inextricably intertwined with, and underwritten by, the kind of loving orientation via which one experiences God. The real, full recognition of God's goodness is that love - and such recognition could not be had without it.

\section{CONCLUSION}

I have argued that al-Ghazālī's conception of experiential knowledge transcends the dichotomy between philosophical rationality and mysticism that Western scholars of religion have used as a lens through which to interpret his work. In the first section, I argued that al-Ghazālî's conception of experiential knowledge doesn't fit comfortably into James and Renan's category of non-rational mysticism because it does, contrary to their assertions, appear to be able to provide a rational basis for belief. In the second section, I argued that al-Ghazālī's conception of experiential knowledge also doesn't fit comfortably into the category of philosophical rationality in which recent authors like Alexander Treiger want to fit it, because it is distinct from the kind of abstract conceptual understanding that is associated with that form of rationality. I closed by highlighting two positive lessons that al-Ghazālī teaches us about why ("mystical") experiential knowledge should not be cordoned off from the realm of the "rational": first, the lesson that experiential knowledge is critical to underwriting motivation for rational action, and second, the lesson that experiential knowledge is uniquely capable of affording its possessor with a genuine understanding of the value (or disvalue) of that which is known. In both these respects, I have argued, al-Ghazālī shows us how rationality can properly enter the emotional, experiential domain of the heart - of how it can be that (as the saying goes) "the heart has its reasons."

\section{ACKNOWLEDGMENTS}

I thank Jawid Mojaddedi, participants in the 2021 annual meeting of the Society for Study of Muslim Ethics, and the reviewers for this journal for their comments on prior drafts of this paper.

\section{REFERENCES}

Adamson, P. (2016), Philosophy in the Islamic World, Vol. 3 (Oxford: Oxford University Press).

Ahmad, I. (2017), Religion as Critique: Islamic Critical Thinking from Mecca to the Marketplace (Chapel Hill: University of North Carolina Press). $<$ https://doi.org/10.5149/northcarolina/978146 9635095.001.0001 > 
Arberry, A. J. (2007), Revelation and Reason in Islam, Vol. 3 (New York: Routledge). $<$ https:// doi.org/10.4324/9780203706930>

Blum, L. (1994), Moral Perception and Particularity (Cambridge: Cambridge University Press). < https://doi.org/10.1017/cbo9780511624605 >

Boyle, M. (2012), "Essentially Rational Animals", in G. Abel and J. Conant (eds.), Rethinking Epistemology, Vol. 2 (Berlin: De Gruyter), 395-428. <https://doi.org/ $10.1515 / 9783110277944.395>$

Coetsee, M. (2020), “The Phenomenal Appreciation of Reasons (Or: How Not to Be a Psychopath)", Oxford Studies in Metaethics 15, 24-48. <https://doi.org/10.1093 /oso/9780198859512.001.0001>

De Boer, T.J. (1903), The History of Philosophy in Islam, trans. E.R. Jones (Amsterdam: Luzac \& Co).

Damasio, A. R. (2006), Descartes' Error (New York: Penguin Books).

Deonna, J., \& Teroni, F. (2012), The Emotions: A Philosophical Introduction (New York: Routledge). <https://doi.org/10.4324/9780203721742>

Dixon, T. (2003), From Passions to Emotions: The Creation of a Secular Psychological Category (Cambridge, UK: Cambridge University Press). <https://doi.org/10. 1017/ cbo9780511490514>

Fodor, J. A. (1975), The Language of Thought (Cambridge, MA: Harvard University Press).

Fodor, J. A. (1987), Psychosemantics: The Problem of Meaning in the Philosophy of Mind (Cambridge, MA: MIT Press).

Frank, R. (1987), “Al-Ghazālī’s Use of Avicenna's Philosophy”, Revue des Études Islamiques 55-57: 271-85.

Frank, R. (1994), Al-Ghazālì and the Ash 'arite School (Durham, NC: Duke University Press).

Al-Ghazālī (1962), The Book of Knowledge, transl. N.A. Faris (New Delhi: Islamic Book Service).

Al-Ghazālī (1977), Marvels of the Heart, transl. W.J. Skellie, PhD Dissertation (Hartford, CT: Hartford Seminary).

Al-Ghazālī (1993a), "Marvels of the Heart" in Revival of Religious Learnings, Vol. 3, transl. F. Karim (Karachi, Pakistan: Darul-Ishaat).

Al-Ghazālī (1993b), "On Disciplining the Soul” in Revival of Religious Learnings, Vol. 3, transl. F. Karim (Karachi, Pakistan: Darul-Ishaat).

Al-Ghazālī (2000a), Deliverance from Error, transl. R.J. McCarthy (Louisville, KY: Fons Vitae).

Al-Ghazālī (2000b), Incoherence of the Philosophers, transl. M.E. Marmura (Provo, UT: Brigham Young University Press).

Al-Ghazālī (2011), Al-Ghazālī on Patience and Thankfulness, transl. H.T. Littlejohn (Louisville, KY: Fons Vitae).

Al-Ghazālī (1997, $2^{\text {nd }}$ edition 2016), Al-Ghazālì on On Disciplining the Soul and On Breaking the Two Desires, transl. T.J. Winter (Louisville, KY: Fons Vitae).

Gairdner, W.H.T. (1914), "Al-Ghazālī's Mishktat al-Anwar and the Ghazālī-Problem”, Der Islam 5.2: 121-153. 
Griffel, F. (2009), Al-Ghazālī's Philosophical Theology (Oxford: Oxford University Press). <https://doi.org/10.1093/acprof:oso/9780195331622.001.0001>

Griffel, F. (2011), “The Western Reception of al-Ghazālī's Cosmology from the Middles Ages to the $21^{\text {st }}$ Century", Dîvân 1: 33-62

Griffel, F. (2016), “Al-Ghazālī” in E.N. Zalta (ed.), The Stanford Encyclopedia of Philosophy. Available at: < https://plato.stanford.edu/archives/win2016/entries/alghazali/>.

Gutas, D. (2016), "Ibn Sīnā [Avicenna]" in E.N. Zalta (ed.), The Stanford Encyclopedia of Philosophy. Available at: <https://plato.stanford.edu/archives/fall2016/entries/ ibn-sina/>.

Ibn Rushd (2002), The Incoherence of the Incoherence, trans. S. Van Den Bergh. Available at: $<\mathrm{http}: / / \mathrm{www} . m u s l i m p h i l o s o p h y . c o m / \mathrm{ir} / \mathrm{tt} / \mathrm{tt}-\mathrm{ns} . \mathrm{htm}>$

James, W. (1902/2002), Varieties of Religious Experience: A Study in Human Nature (New York: Routledge).

Jantzen, G. M. (1989), “Mysticism and Experience”, Religious Studies 25.3: 295-315. $<$ https://doi.org/10.1017/s0034412500019867>

Kant, I. (1800/1978), "Preface to Reinhold Bernhard Jachmann" in A. Wood (ed.), Kant's Rational Theology (Ithaca: Cornell University Press).

King, R. (2013), Orientalism and Religion: Post-Colonial Theory, India and “The Mystic East” (New York: Routledge). <https://doi.org /10.4324/9780 20300 $6085>$

Leaman, O. (2002), An Introduction to Classical Islamic Philosophy (Cambridge: Cambridge University Press). <https://doi.org/10.1017/cbo9781139164719>

Kukkonen, T. (2008), "The Self as Enemy, the Self as Divine: A Crossroads in the Development of Islamic Anthropology" in P. Remes and J. Sihvola (eds.), Ancient Philosophy of the Self (Amsterdam: Springer Netherlands), 205-224. <https://doi. org/10.1007/978-1-4020-8596-3_11>

Kukkonen, T. (2012), "Receptive to Reality: Al-Ghazāli on the Structure of the Soul", The Muslim World 102.3-4: 541-561. <https://doi.org/10.1111/j.1478-1913.2012. 01412.x >

Kukkonen, T. (2015), "Al-Ghazālī on Emotion" in G. Tamer (ed.), Islam and Rationality: The Impact of al-Ghazālì, Vol. 1. (Leiden: Brill), 138-164. < https://doi.org/10.1163/9789004290952_008>

Nakamura, K. (1984), "Makki and Ghazālī on Mystical Practices”, Oriens 20: 83-91. $<$ https://doi.org/10.5356/orient1960.20.83>

Nussbaum, M. C. (2003), Upheavals of Thought: The Intelligence of Emotions. (Cambridge: Cambridge University Press). <https://doi.org/10.1017/cbo97805 11840715>

Nussbaum, M. C. (1992), Love's Knowledge: Essays on Philosophy and Literature (Oxford: Oxford University Press).

Mawson, T.J. (2005), Belief in God: An Introduction to the Philosophy of Religion (Oxford: Oxford University Press).

Moosa, E. (2005), Ghazāli and the Poetics of Imagination (Chapel Hill, NC: University of North Carolina Press). 
Picken, G. (2011), Spiritual Purification in Islam: The Life and Works of al-Muhasibi (New York: Routledge). <https://doi.org/10.4324/9780203835043>

Renan, E. (1852, $3^{\text {rd }}$ edition 1866), Averroès et l'Averroüsme: Essai Historique (Paris: Michael Levy).

Renard, J. (2004), Knowledge of God in Classical Sufism: Foundations of Islamic Mystical Theology (New York: Paulist Press).

Siegel, S. (2014), "Affordances and the Contents of Perception" in B. Brogaard (ed.), Does Perception Have Content? (Oxford: Oxford University Press). <https://doi. org/10.1093/acprof:oso/9780199756018.003.0003>

Solomon, R. (2003), Not Passions Slave: Emotions and Choice (Oxford: Oxford University Press).

Solomon, R. (2007), True to Our Feelings: What our Emotions are Really Telling Us (Oxford: Oxford University Press).

Stocker, M. (1983), "Psychic Feelings Their Importance and Irreducibility", Australasian Journal of Philosophy 61.1:5-26. < $<$ ttps://doi.org/10.1080/ $00048408312349841>$

Treiger, A. (2012), Inspired Knowledge in Islamic Thought: Al-Ghazālì's Theory of Mystical Cognition and its Avicennian Foundation (New York: Routledge Press). $<$ https://doi.org/10.4324/9780203806487>

Winter, T.J. (1997, $2^{\text {nd }}$ edition 2016), "Introduction" in Al-Ghazālì on Disciplining the Soul \& On Breaking the Two Desires (Louisville, KY: Fons Vitae).

Yazaki, S. (2012), Islamic Mysticism and Abu Talib al-Makki: The Role of the Heart (New York: Routledge). <https://doi.org/10.4324/9780203073544>

Zagzebski, L. (2003), "Emotion and Moral Judgment", Philosophy and Phenomenological Research 66.1: 104-24. <https://doi.org/10.1111/j.1933-1592. 2003.tb00245.x >

Zagzebski, L. (2004), "Making Emotion Primary", in Divine Motivation Theory (Cambridge: Cambridge University Press), 51-94. < https://doi.org/10.1017/cbo $9780511606823.004>$ 